\title{
Harmonious Resolution of Controversy (Acts 15:1-35) Panacea for Integral Development of Any Society.
}

\author{
Rev. Fr. Dr. A.I. Ezeogamba \\ Chukwuemeka Odumegwu Ojukwu University Anambra State \\ (revtonyiyke@yahoo.com)
}

\begin{abstract}
.
Jesus, the head of Christianity, left few adherents mainly from among the Jews. He urged his disciples (those he had already made his followers) as he was about leaving the world to go into the world and make disciples of all nations, ordering them to "Baptize them, In the name of the Father and of the Son and of the Holy Spirit" (Matt 28:19). This admonition coupled with the indwelling of the Holy Spirit, vivified the disciples in their missionary enterprise to the extent that Christianity embraced various nations with their various cultures and natural inclinations. In Acts 15:1-35 the meeting of different cultures brought about controversy which nearly rocked the Gentile mission and indeed the entire missionary enterprise. Peaceful resolution of the misunderstanding brought about proper definition of what Christianity is all about (which is salvation by faith in Jesus Christ) and subsequent universal development of the church. It was as a result of the harmonious resolution of that controversy that made both the Jews and Gentles to feel welcomed in the one family of Christ hence the innumerable number of Christians today. In our society today, integrated development is hindered because of various unresolved controversies. This article aims at identifying the reason why there is no integral development in very many societies and organizations and proffering solution to that effect. It argues that if the leaders of various organizations and societies were to understand properly the actions of the apostles, elders and the church in Acts 15:1-35 and imbibe it, then integral development would be assured. The method we shall adopt is library research which is mainly an exegetical analysis of Acts 15:1-35.
\end{abstract}

key words: Harmony, Controversy, Resolution, Development, Society.

\section{INTRODUCTION:}

Jesus Christ was born a Jew, lived, died and buried a Jew (Luke 2:21-24; 2:41-42; John 19:40). He had his immediate followers who were all Jews. He trained them for them to train others and handed over the mantle of leadership to them. It was within the post resurrection period or rather shortly before ascension that He gave His disciples the mandate to universalise His teaching (Matt 28:18-20). Peter and indeed the rest of the apostles went into action and converted many Jews, as much as three hundred (Acts 2: 37-41). From that day on wards, even Jews in Diaspora heard the good news and became Christians. These include Greek speaking Jews or Hellenists. In fact, from among the Jews, almost all Jewish sects were represented in this new assembly especially the Pharisees. The common denominator is that they were all Jews or those that have been made Jews through birth or slavery. Even among the Jews that have become Christians, there arose also quarrel between the Hellenists and Hebrews, but this church promptly settled this initial controversy through the institution of the seven deacons which included Stephen (Acts 6:1-7).

It was in obedience to the command of Jesus, for his followers to 'disciple all nations', that Peter led by the Spirit converted and baptized Cornelius (a Roman centurion) and his entire household (Acts 10:44-48). With the death of Stephen, the first Christian martyr, Christianity spread outside the fold of the Jews which included Antioch and surrounding nations (Acts 11:19-21). Again, with the conversion of Paul, and the stubbornness of the Jews, the missionary zeal towards the Gentiles increased greatly. Most of the Gentile conversions came from Paul which include (i) conversion of Sergius Paulus (Acts 13:6-12); (ii) Conversion of many Gentiles in Antioch of Pisidia (Acts 13:42-49); (iii) conversion of Greeks in Iconium (Acts 14:1); (iv) conversion of Cornelius and his household (Acts 10). All the above conversions came from Paul with the exception of the last one.

The entrance of Gentiles into the family of Christ brought serious controversy as a result of the misunderstanding of Christ event- suffering, death on the cross, burial and resurrection of Christ. Earlier

African Journal of Education, Science and Technology, April, 2016 Vol 3, No. 2 
than now, is like the apostles and disciples of Jesus from Jewish extraction believed that there is no salvation without circumcision. The implication is that, only the Jews who are circumcised that would be saved and Jewish converts. Hence, placing circumcision above the shading of Christ's blood on the cross; thereby rendering useless the reason of Jesus' birth, and death. The Judaizers, i.e. those that uphold tenaciously the traditions of their ancestors and those who insist that salvation lies with circumcision and Laws of Moses, claim that anyone that wants to become a Christian must first of all become a Jew. This idea, if upheld, would have made Christianity another sect within Judaism.

\section{JUDAISM AND HER SECTS}

Jesus met three main Jewish sects and they include: The Pharisees, Sadducees, and Essenes. Each of these schools have their schools and followers. Our interest is restricted to the first Sect, which is the Pharisees for the sake of this article. The Pharisee sect is rightly called the Law experts and quarrelled with Jesus more than any other group because of their blind obedience to the Law. They never had it easy with Jesus and hence received the highest condemnations from Jesus (Matt 6:2, 5,16; 15:7; 23). They are the group John the Baptist called "brood of vipers" who rested complacent in their having Abraham as their progenitor (Matt 3:7-8). They are exact observers of the Law of Moses. Their progenitor are the Hasidaeans. The Hasidaeans, a transcription of the Hebrew chasidim, - (Hasidim) i.e., pious ones, were a society of men zealous for religion, who acted under the guidance of the Scribes, in opposition to the godless Hellenizing party (Sadducees); they scrupled to oppose the legitimate High Priest even when he was on the Greek side. Their fundamental principle was complete separation from non-Jewish elements, they were the strictly legal party among the Jews, and were ultimately the more popular and influential party. Hence, legalism is their watch word (W.E. Vine,1997:853). It is no exaggeration to say that they follow law sheepishly. They follow Law without understanding the spirit of the Law or the Law giver. Their interest is on the letters of the Law. Josephus observed that when the Jewish people faced an important decision, they relied on the opinion of the Pharisees rather than that of the king or high priest (J.I. Packer and M.C. Tenney Eds., 1980: 506). Let us not forget that Paul (Saul) was a member of this sect before his conversion to Christianity (Phil 3:4-7; Gal $1: 14)$. Hence, the solution to the controversy that this article wants to portray as a model for settling disputes for integral development to thrive was really a controversy between Paul's community and Pharisaic sect. Let us at this stage look at how this separated group values the Gentiles.

\section{GROUPS OUTSIDE JUDAISM - GENTILES:}

The Hebrew word goyim, Latin word gens and the Greek word ethnos (Josh 24:11) has sometimes been translated 'nations, Gentiles, heathen.' Gentiles has applied to all nations other than the Jews (Watts, J. Wash, 2005: 670). The word Gentiles was first applied to the descendants of Shem, Ham, and Japheth (Gen. $10: 5,20,31)$ without any distinction. Distinction only came with Abraham being called by God to be the father of the chosen people of God (Exod 19:4-6). From that grows the idea that Israelites who keep the covenant of God with faithfulness are regarded as nation of God (Psalm 106:5; 9:5), whereas those who do not are called just 'the nations, Gentiles, heathen' (Isa 60:3; Acts 13:47; 10:16). Thus to think of the nations, is to think of idolatry, people who are corrupt and those who do things that are not in harmony with commandments of God (Lev. 18).

According to some ancient traditions, the Israelites were asked to be separated from them in every ramification be it marriage, religion, and politics (Exod. 23:28-33; Deut. 7:1-5; Josh 23:4-13; 2 Mac 14:38). Those were traditions before Christ. Christ came to change all that. He came to reconcile humanity as a whole back to God. He came to settle the eternal enmity between the Jews and Gentiles. The Pharisees no doubt do not understand the message of Christ which is the breaking down of the barrier between nations which is the barrier between the Jews and Gentiles (Eph. 2:14). Paul fought tooth and nail the efforts to distinguish between Jew and Gentile in the Christian community (Rom. 3:29-30; Gal. 2:11-21; 3:26-29). He received several oppositions (Gal 2:12). Paul's insistent, according to David W. Suter, "furthered the success of Christianity within the empire and led to its emergence as a distinct religion by the end of the first century" (1994:339). Without Paul who made this insistence to release the Gentiles from this type of bondage, Christianity would have remained a sect within Judaism.

\section{BRIEF HISTORY OF ACTS OF APOSTLE}

In a simple term, Acts of the Apostle is the product of that command which Jesus gave to his disciples in Matthew 28:18-20. In other words, it is the record of event that took place after the departure of Jesus from 
the universe. It is the sum total of the works done by the apostles and their converts through the guidance of the Holy Spirit. Scholars are unanimous in affirming that Acts is no doubt the "history of the rise of Christianity" (Henry Wansbrogh [Gen.Ed.], 1984:1794). It then means that Acts brings to focus the history of the beginning of Christianity. This fact authenticates the demands of Jesus when he says, "You will be my witnesses not only in Jerusalem but throughout Judea and Samaria, and indeed to the earth's remotest end" (Acts 1:8). Acts 1-5 exposes how this extensive work got its firm root in Jerusalem. This fact was corroborated by Michael D. Coogan (ed) when he wrote, "The book of Acts tells a dramatic story of the birth and expansion of the Church from the time of the ascension of Jesus until the arrival of Paul in Rome" (2001:183).

One wonders why the title 'Acts of the Apostles' which supposes to be the actions of the twelve apostles after the death, and ascension of Jesus. Some scholars would have even preferred to name the book 'Acts of Paul' since it records more the persecution wrought by Paul, his conversion and great role he played in fighting for the independence of Christian Community from remaining a sect of Judaism; again coupled with the fact that the book ends with the arrival of Paul to Jerusalem. Coogan wrote, "As a title, Acts of the Apostles is clearly a misnomer, since Peter is the only apostle who receives individualized portrayal. Nevertheless, it does capture one of the key concepts of the book, namely, that the apostles guarantee continuity with Jesus through their status as witnesses to everything that happened during his ministry (Acts 1:21-22), this testimony applies above all to his resurrection (Acts 10:39-41)" [183]. Without minding any contrary voice, it is good to note that it was the apostles, who inaugurated the elders, to head the various communities they (apostles) gathered and through the promptings of the Holy Spirit all the missionary enterprise of Paul to the Gentiles were ratified (Acts 15:1-35). Hence this book records the continuation of the works Jesus started in the Gospels. Among all the documents of the earliest Christian period, this book offers a narrative sequel to the accounts of Jesus' words and deeds found in the Gospels (Coogan:183).

Scholars are almost unanimous in affirming that Acts of the Apostle is the second volume of the two books written by Luke in the New Testament. It is not easy to point out any dissenting voice to this fact. He (Luke) first wrote Gospel which deals with the birth, life, teaching, suffering, death, burial, resurrection, and ascension of Jesus into heaven (John 1:1-2). The second volume deals with actions of the Apostles and their converts as well as the promptings of the Holy Spirit in extending the mission of Christ to all parts of the world (Acts 1:1-2). The purpose of Luke in this second volume is to "imbue Christians of his day with an unshakable confidence in their future through a didactic survey of their past" (Coogan:183.). In doing this, he made effort to solve other socio-cultural, and theological problems brought about by the relationship of the new community with its Jewish heritage and as well as its Roman socio-cultural and political environment.

Let us summarise this background information with this beautiful articulation by Henry Wansbrogh as it affects this work we are developing:

The most urgent problem facing the new church was the admission of gentiles, and Acts provides important details about this, without, however, revealing the full extent of the difficulties and disagreements this must have caused within the Christian community, and even between its leaders (Gal 2:11-14). The Jerusalem brotherhood led by James remains faithful to the Jewish Law (Acts 15:1,5; 21:20ff) but the Hellenists, for whom Stephen acts as spokesman, want to break away from Temple worship. In Luke's account, Peter, but even more so Paul, gets the principle of salvation through faith in Christ recognised at the council of Jerusalem (1797).

The whole book therefore centres its central message on the fact that salvation depends on the faith one has in Christ. It emphasizes that just as circumcision is for entrance into Judaism, baptism is absolutely necessary for entrance into community of believers. It affirms that one does not really need to be a Jew in order to become follower of Christ. For Acts, circumcision is for Old covenant and Baptism is for the new covenant. Thus, separating Christianity from Judaism and encourages the growth and expansion of Christ's event to the ends of the earth. 


\section{STRUCTURALANALYSIS OF ACTS 15:1-35}

The events of Acts 15:1-35 raise several difficulties which include Vv 1-2 is repeated in vv 5-7. Some scholars see this repetition as two different accounts of two actions concerning the controversy that tends to rock the Gentile community in Antioch. Others see it as the same account but repeated as a result of the short meeting which was held between the executive fold before the general assembly. But a close study reveals that if one holds that there was private meeting as verse 6 suggests before the general meeting, one can easily be contradicted by vv 12-22 which suggest order wise. Verses 12-22 suggest that the debate from the beginning involved all the assembly. Again, though the decree of v29 was intended for the churches of Syria, and Cilicia, in v23 Luke has nothing to say about Paul's publishing it when he travelled through those provinces (v41) but the decree of vv 19-21 incline to show that the decree was meant for Gentiles as a whole. In this write up, irrespective whatever argument that is being adduced by scholars to suggest that our text deals with two distinct controversies, we shall maintain our ground to take it as single event and that the repetition is nothing but literary device. So, in spite of these little dissenting issues, Acts 15:1-35 is a unit.

Acts 15:1-35 is a unit. It starts with the arrival of self acclaimed teachers from Jerusalem to Antioch which generated unimaginable controversy that would have destroyed the church if not for the quick intervention of the Jerusalem Church. The story equally ended with authoritative intervention from Jerusalem Church to the Antiochene church. The problem was introduced in the community of Antioch by false teachers from Jerusalem church and was equally resolved by authoritative, true messengers, and letters from the Jerusalem community to the Antiochene community. We shall interpret this all important text by dividing it into the following sub heads namely:(i) of Elders (Jewish) And Redemption Wrought by Christ in Contest Vv 1-4; Arrival of the Emissaries to Jerusalem (vv 5-6); Peter's and Antiochene Emissaries' Speech (vv 7-12); James' Speech and Proposal for the Antiochene Church (vv 13-21); The Jerusalem Decision (vv 22-29); The Delegates and the Message (vv 30-35); After Effects of the Letter. In each of these sections, we shall first of all look at some key words that will help us to interpret each section well.

Tradition of Elders (Jewish) And Redemption Wrought by Christ in Contest Vv 1-4

Certain men came down to Antioch from Judae. Such people were also mentioned in Gal 2:12. The term Judea may occasionally be used to mean all the region occupied by the Jewish nation. Several of Luke's references seem to be the most conclusive (Luke 23:5; Acts 10:37; 26:20). From every intent, they are Judaizers from Jerusalem Church who were struggling to subjugate the why of Christ to Judaism; hence taking Christianity to be a sect within Judaism. But who were the Judaizers then, "this is an extra-biblical term for those who acted like Jews and/or sought to influence others, based on Paul's charge that Peter's attitude would force Gentiles 'to judaize' (Alcorn:965). That means, to become or live like the Jews (Gal 2:14). So anyone who struggles to enforce circumcision and other Jewish legal norms (Laws of Moses) to none Jews is a judaizer. William Baird in his effort to identify the men from Judea says, they "are converts who belonged to the party of the Pharisees. Coming out of a legalistic background they believe the law of Moses must be obeyed by Christians (1983: 56). What is certain is that no one permitted this group to meet with Antiochean Christian community (v.24).

Vv.1-2 introduce the coming of the Judaizing teachers in Antioch. In Gal 2:12, they are introduced as people who came from James. But here it was not specified. They began to teach the brothers that "unless you have yourselves circumcised in the tradition of Moses you cannot be saved". Thus making circumcision a prerequisite condition for salvation. Their conviction was because it was prescribed by the custom/tradition (ethei) of Moses. But one knows that long before Moses, God established a covenant between him and Abram and subsequently Abraham's descendants. One wonders why urging them to be circumcised according to the tradition or custom of Moses instead of that of Abraham. Maybe because, Moses took it upon himself to enforce it to the general assembly of the Jews since they used to read it on the Sabbath days. Besides, to talk of Moses is to talk of the Law, hence he has been acclaimed to be the highest law giver in the whole bible.

The Gentiles were very happy when the good news was preached to them by the Jews. Their joy and hope was dashed by the judaizers that just arrived in their community. They insisted that circumcision is very important for them. This no doubt stirred no small dispute or controversy in the Church of Antioch (Taylor:1604). Let us at this stage understand what circumcision is all about. 
The Greek word peritmethete is an aorist, passive term, subjunctive mood, from the word peritemno meaning to 'circumcise.' Circumcision from the beginning signifies that anyone who would have anything to do with the Jews must be circumcised (Gen 34:14; Exod. 4:24-26; Lev. 19:23). It qualifies one even to marry a Jewish woman, to eat, play or worship with the Jews. It is only a sign that makes one a Jew. In Gen. 17:114 circumcision stands to remind both God and the Jews of the covenant they entered into. In it, God is their father and they are sons of God. In the same way, the rainbow in Gen 9:16-17 is a sign to God and all creatures that they are in a covenant with God. While rainbow is a sign of covenant with whole humanity, circumcision is a sign of covenant between God and only the chosen people, the descendants of Abraham (Gen 17). This restricted covenantal sign has its obligations and responsibilities which include obedience or fidelity to the Law (Exod 19:5; 24:7-8) and to Sabbath observance in particular (Exod. 31:16-17).

These Judaizers should not be blamed in anyway, because they were at the time reacting against those who were trying to push them away from the tradition in which they were brought up. Whatever they were doing to defend the tradition handed over to them was in order because they were really acting out of ignorance. They fought with the same zeal Saul fought with so as to destroy Christianity before his conversion (Acts 9). Paul (Saul) after his conversion, he removed the yoke of Judaism and put on the yoke of Christianity. He accepted that the only road that leads one into the community is baptism. This was why he embraced wholly the charge given by Jesus to his apostles in Matt 28:18-20.

These explanations will help us to understand why there was a heated argument between the Judaizers that came down from Jerusalem and the Christian teachers like Paul and Barnabas in verse 2. Each of the group seem to have talked out of conviction. Let it be said immediately that both groups were under the influence of the Holy Spirit, otherwise, they would not have accepted to go to Jerusalem for the clarification of idea so as to settle the controversy. Hence, Paul and Barnabas and the other unnamed members of the Church were detailed to go to Jerusalem for the sake of peace. Among the unnamed members of the delegation, some scholars have named Titus as being part of that group (Gal 2:1-3) most importantly because he has a gentile blood. Though this is a mere speculation, but it seems most plausible because one is supposed to be where his case is being discussed.

On their way (v3), they passed through Phoenicia, and Samaria. Some scholars even assume that the emissaries did not move straight to Jerusalem, but they made effort to visit as many churches as possible to break the good news to them (Rickard: www.themoorgngs.org). Those they met While on the way and the Christian brothers and sisters they met on the arrival were highly delighted. That is, the news of the conversion and welcoming of gentiles into the Church was received with great joy and the Judaizers were aware of this development. This must have helped to weaken the courage of the Judaizers as they moved towards the meeting in Jerusalem. It helped to reduce the Judaizers to "a splinter faction in the church" (Dillon: 751).

\section{ARRIVAL OF THE EMISSARIES TO JERUSALEM (VV 5-6)}

When these arrived Jerusalem, they were seemingly welcomed warmly. They were welcomed by the apostles, elders and indeed the entire church. There is no doubt that under neat the enthusiastic group that welcomed them were judiazers who must be struggling on the strategy to deal and defeat them into submission. To assume that the Judaizers were also happy in welcoming Paul and Barnabas to Jerusalem is being economical with the truth. The atmosphere was seemingly cordial preempting what would be the outcome of the deliberation. What is very clear from that encounter is the openness with which majority approached the dialogue table. They met each other in the openness of mind. Hence, one notices that before there could be any meaningful dialogue, there must be willingness of both sides to meet and willingness to accept the outcome of the meeting.

There is a little discrepancy between v6 and v12. In v6 we read that apostles and elders met but in v12 we read that the entire 'assembly' were silent. The western text has the addition of 'assembly' i.e. 'apostles, elders and assembly' met. This last information is more plausible.

Verse 1 presents the circumcision party as people who claim that circumcision is absolutely necessary for salvation but verse 5 presents circumcision as prerequisite for social participation in the Christian community. When the issue why the emissaries came to Jerusalem was tabled before the entire assembly, therefore, there 
were heated debate. This debate was really initiated by the Pharisees who were newly converted to Christianity. Peter and others who know the truth kept their faith. At a point, according to the Western text, Peter was' prompted by the Spirit' and he spoke up. He stood to challenge the spirit that was about to derail the faith; to express that some of those who were arguing do not really understand the full import of the blood Christ shaded on the cross. Peter stood up to explain the difference between tribal gospel and the gospel of Christ.

\section{PETER'S AND ANTIOCHENE EMISSARIES' SPEECH (VV 7-12)}

After the heated argument, Peter, an authority in the mission Christ entrusted to his followers before departing from this universe spoke up. The speech of Peter came in vv 7-11. Peter saw the circumcision as an unnecessary burden on the converts. Peter's speech seems to have ended the issue at hand to the extent that no one mentioned it again. He reminded them that it was through him as destined by God that the first Gentile converts got their conversion v.7 (Acts 10:44-45). He reported that it was exactly what happened to them at Pentecost (when the Holy Spirit descended on them) that happened to the gentiles during their own time, i.e. they received anointing also as the apostles did (v8). The implication is that God has no favorite (v9; see also 10:34-35). Peter really spoke like Paul in Gal 2:16; the emphasis is that salvation or anointing is a gratuitous gift from God. Hence, no one can claim that he merited it through his obedience to the Law (Rom 11:32; Gal 2:15-21; 3:22-26; Eph 2:1-10). This assumption of Peter throw away the importance attached to circumcision as the necessary condition for salvation (v1). What Peter said raise very highly the moral of Paul and Barnabas. For them their mission has been accomplished with the speech of Peter. The speech of Peter provoked sober reflection in the minds of all present to the extent that silence prevailed in all direction (v12a). In fact, the voice of Peter sounded like a voice everybody was waiting to hear. His speech ended every argument.

It was only then that Barnabas and Paul added their voice to authenticate or concur with what Peter had said. This time, they were not really propounding any new doctrine but just to give testimonies of what God accomplished through them when they ministered to the Gentiles (v12b). The voice of Barnabas and Paul only strengthened the solid rock Peter had already laid.

\section{JAMES' SPEECH AND PROPOSAL FOR THE ANTIOCHENE CHURCH (VV 13-21)}

James having heard all that Peter had said, which touched him deeply as well as others, argued that what Peter said was already propounded by prophet Amos (9:11-12) using the Septuagint edition. Amos, according to James, had prophesied that before the second coming, the fallen hut of David would have been repaired (vv 13-18). James as the presiding officer of the Jerusalem Church concurred with what Peter said and urged the assembly that the church should avoid laying a heavy burden on the shoulders of the new converts from the Gentile World (vv 19-21). He subsequently listed four things the Gentiles would be asked to avoid or abstain from. James was against those that were laying heavy burden on the new converts (v19). But even in the midst of not being with those who lay heavy burden on them, he believes that there must be some commitment from the Gentiles. The relationship in the new assembly will be a mutual assembly where the Jews must let something go and the Gentiles must also sacrifice something. Hence, "The result of the conference (in contrast to Gal 2:6-10) is a compromise. Circumcision is not required for salvation, but Jewish ritual requirements are essential to fellowship" (Baird: 58).

In order to accommodate the Gentiles without circumcision and observing other laws of Moses they were asked to avoid some avoidable old ways which includes "abstaining from (1) things polluted by idols (this refers to the meat of animals killed for heathen sacrifices (v29; 21:25; Col 8:10); (2) from illicit marriages (This include all the irregular marriages listed in Lev. 18); (3) from the meat of strangled animals; and (4) from blood (blood symbolizes life which belongs to God alone Lev 1:5);" Talor calls the illicit marriage "fornication" (1605). Every detail of these four issues the Gentiles were asked to run away from are still part and parcel of the tradition the Jews received from their forebears as recorded in Lev. 17 and 18. In these two chapters it was clearly stated how Jews were to live with Gentiles who are living in their midst. For instance, Lev. 17:1-9 state that to God alone should sacrifice be offered. Next comes the commandment not to consume the blood of any creature, since life is in the blood and belongs exclusively to the giver of life (Lev. 17:10-14) [Jerusalem Bible Note: 1825]. Similarly, both Israelites and foreigners will become unclean if they eat the flesh of an animal that has died a natural death or been savaged (Lev. 17:15-16). As for 
fornication, this term covers all the forms of unlawful sexual union that are prohibited in Lev. 18 and are forbidden to Israelites and to foreigners alike (Talor 1605). James judgment "embodies the authoritative conclusions of the Church. That Jewish Christians should not trouble the Gentile converts refers to the yoke (v 10) and implies that circumcision is not to be required. The requirements which are made (v20; c.f. v29) constitute the apostolic decree" (Baired: 58).

Gal 2:9 testifies to the importance of the part played by James in this matter especially in the controversy over local problems of social relations (Acts15:1a, 20). One is right, therefore, to say that the part played by James in this particular chapter can never be over emphasized. Let us conclude this section by saying that James settles the controversy, and the terms of the apostolic letter are those of his own pronouncement. This is because as at that as Gal 2:9 suggests, he occupied the first place in the Jerusalem church (Acts 12:17-18).

\section{THE JERUSALEM DECISION/APOSTOLIC DECREE (VV 22-29)}

The decision reached by the apostles, elders and the entire church is more of a concession than a decree. Israelites knew things that may likely make them unclean according to their tradition and asked the Gentiles to avoid them. Again avoiding them would never cause the Gentiles any indignities; instead it will raise their status. It is like saying, 'if you must be my friend, then you must avoid falsehood.'

The council was very meticulous in sending their message back to those it was meant for. Instead of sending back to Antioch only Paul and Barnabas with the set of concessions they agreed on, the council so as to authenticate their message and for their message to be delivered as agreed, they send down to Antioch also Judas son of Sabbas and Silas to send the message to the Antiochean Christian community and to the whole Gentile world (vv22-23). The essence of this was to prove to the Gentiles that what they have as letter from the apostles, elders and the whole assembly is authentic. The tone of the letter was highly encouraging. It specified that the letter came from 'the brothers, both the apostles and the elders' and that the letter was meant for the 'believers of Gentile world that are of Antioch, Syria and Cilicia' origin (vv 23-27). The letter reminded them that those who came previously to them to lay heavy burden on them came on their own accord and never from the authority of the Jerusalem Church. Above all, the letter claimed that the decision they have taken were not really theirs alone, but it was taken in union with the Holy Spirit. The implication is that there were four groups in the decision namely, the apostles, the elders, the church, and the Holy Spirit. The letter reads in part: "It has been decided by the Holy Spirit and by ourselves not to impose on you any burden beyond these essentials: you are to abstain from food sacrificed to idols, from blood, from the meat of strangled animals and from illicit marriages. Avoid these, and you will do what is right. Fare well" vv 2829: NJB). The Jerusalem concession shows a complete confidence that it worked with the Holy Spirit (Talor 1606).

Those that were chosen to send the message to Antiochene Christian community are men of proven character. They have the integrity that commands respect (v22-23). Silas for instance, became a missionary companion of Paul from after the delivering of the message (Acts 15:40-18:5.) He is the same as the Silvanus mentioned in 2 Cor.1:19; 1Thess 1:1; 2Thess 1:1 and 1 Peter 5:12). He was not a hidden member of the Church even before this event. "The letter denounces the Judaizers of verse 1 and commends its bearers as men who have risked their lives for the Lord's sake" (Baird:59).

\section{THE DELEGATES AND THE MESSAGE (VV30-35)}

The messengers arrived Antioch and summoned the whole community and read the letter to their hearing. Baird said, "In sending the letter, the Jerusalem leaders assume authority over a wide area. Actually, it is addressed only to the Christians of Syria and Cilicia, but Paul delivers its decisions to the Churches founded on his earlier mission (16:4), and James considers it directed to all Gentile Christians (21:25)" [59]. There is nothing wrong with that, after all, the letters of Paul we are reading today were not originally meant for us but were written to those communities to solve one problem or the other. We are reading them today because those problems Paul set out to solve with those letters are still the problems of our own time. The community was highly delighted with the encouragement the letter gave them.

They were very happy that their Jewish brothers have fully accepted them to be together with them under Christ. Their joy knew no bounds when they heard that they were called "brothers" by the members of the Jerusalem Church. They were very happy that the barrier between them have been knocked down. "The 
people were glad for the encouraging news that would, at least for now, resolve the conflicting teaching. This may very well have been gladly received by the Antioch Judaizers, since they would no longer feel like spiritual policemen going around accusing the Gentile Christians of an incomplete faith" (www.biblicaltheology.com/arts/44.15). The whole group both Jews and Gentile that gathered "responded with great rejoicing. They glorified God for releasing the Gentiles from circumcision and all the other difficult requirements of the ceremonial law" (Richard, www. themoorings.org/expositions/acts/chap15. The arrival of the Jerusalem delegates to Antioch opened a new page in the history of Christianity. With the reading of the apostolic letter from Jerusalem Church and explanation that followed from Silas and Judas and the irresistible joy that heralded it, the letter sealed the fact that Christianity is not a sect in Judaism but an advancement on Judaism or Jewish ethnic religion. Hence, though Christianity has its root in Judaism, it is universal and not ethnically bound.

\section{AFTER EFFECTS OF THE LETTER}

Earlier before the council's meeting in Jerusalem, Paul and indeed the whole apostles were afraid to preach comfortably in the midst of the Gentiles but after the apostolic letter new zeal entered into Paul and other apostles. After the dialogue at Jerusalem, the expansion of the church was like a wild fire. It became catholic on the true sense of the word.

Paul moved out through Lycaonia, crossing Asia Minor, arrived Philippi, Thessalonica, Beroea, Athens, Areopagus council meeting. From Athens he went back to Jerusalem through Asia, Macedonia and Achaia, Ephesus, Troas to Miletus, and then to Jerusalem. From Jerusalem with all the problems he faced, he appealed to Rome. Rome was where he finished his missionary enterprise (Acts 28: 30-31).

Let it be reiterated again that it was as a result of the harmonious resolution of the conflict that would have destroyed the church as a universal church that Christianity is now in all parts of the world including Achina my home town. Those who came for the dialogue in Jerusalem were open minded and were ready to listen to the opinion of others and that is why the conflict was amicably resolved. If not for the timely intervention, maybe the church or Christianity would have remained as another type of sect within Judaism like the Pharisees, Sadducees and Essenes. In conclusion, it is now clear from the example exhibited by the apostles, the elders, the entire Christian assembly of Jerusalem, as well as Paul and Barnabas (representing Antioch Christians), Peter and James i.e. openness to dialogue that brought about harmonious resolution of the controversy. This goes a long way to show that harmonious resolution of controversy remains an inevitable panacea for integral development of any society (Acts 15:1-35). Companies, societies, organizations, countries where members or citizens cannot gather to discuss their problem cannot progress or develop.

\section{REFERENCES}

Achtemeier, J. P. (1994). (Gen Ed). Harper's Bible Dictionary. Bangalore: Theological Publications in India.

Acts 15. http://www. biblestudy tools.com/commentaries/ jamieson-fausset-brownn/acts/acts-15.,4/8/15

American Journal of Biblical Theology. http://www.biblicaltheology.com/act/. 4/8/15

Coggins, R.J. and Houlden, J.L (1990). (eds.) A Dictionary of Biblical Interpretation. Philadelphia: Trinity Press International.

Dillon, J. R (1990). Acts of the Apostles. The New Jerome Biblical Commentary (4th ed.). Hendon: Geoffrey Chapman.

Matthew Henry's Concise Commentary. Acts 15. http://www.Christnotes.org./commentary. 4/8/15

Packer, J.I. and Tenney, M.C. (1980). (Eds) Illustrated Manners and Customs of the Bible. Nashville: Thomas Nelson Publishers.

Pfeiffer, F. C. Vos, F. H. and Rea, J. (2005). (Eds.) Wycliffe Bible Dictionary Massachusetts: Hendrickson Publishers.

Rickard, Stanley Edgar. http://www.themoorings.org/expositions/acts/chap15.html. 4/8/15

Rienecker, F. (1980). A Linguistic Key to The Greek New Testament. Michigan: Grand Rapids.

Talor, J. (2004). Acts of the Apostles," The International Bible Commentary. Bangalore: Theological Publications in India.

The New Jerusalem Bible (SE). London: Darton, Longman \& Todd. 1985.

The R.S.V. (1958). Interlinear Greek-English New Testament. Michigan: Grand Rapids.

"The Book of Acts" http://executableoutlines.com/acts-so/ac15. 4/8/15.

Vine, W.E. (1997). Vine's Expository Dictionary of Old \& New Testament Words. Nashville: Thomas Nelson Publishers. 